\title{
State of South African Public Service in the Context of Macro Socio-Economic Environment
}

\author{
Professor Modimowabarwa H. Kanyane (Corresponding Author) \\ Chief Research Specialist: Democracy, Government and Service Delivery \\ Human Sciences Research Council, 134 Pretorius Street, Private Bag X41, Pretoria, 0001 \\ Ph \#: +27 (0)82 $3241338 \quad$ Email: hkanyane@hsrc.ac.za \\ Dr Gregory F. Houston \\ Human Sciences Research Council, 134 Pretorius Street, Private Bag X41, Pretoria, 0001
}

Mr Kombi Sausi

Human Sciences Research Council, 134 Pretorius Street, Private Bag X41, Pretoria, 0001

Received: December 23, 2012 Accepted: February 21, 2013 DOI: 10.5296/jpag.v3i1.3267

\begin{abstract}
The Constitution of the Republic of South Africa 1996 requires the public service to embody certain enshrined democratic principles and values and be able to perform effectively and efficiently. The Constitution stipulates that the public service has to be professional, efficient in the use of resources, development-oriented, impartial in the provision of services, and responsive to the needs of the people. It should be accountable and transparent, perform effectively and efficiently in meeting all the tasks of government, and have the institutional capacity and organisational ethos to perform the tasks of government effectively. In each of these areas the Public Service faces a number of challenges, determined by, among others, the macro-socio environment. It is on this bases that the authors provides an analyses of the macro-socio environment in which the public service operates and propose a professional single public service, subject to merit-based selection and promotion processes.
\end{abstract}

Keywords: Public service, socio economic environment, governance and corruption 


\section{Introduction}

The South African public service is required to embody certain constitutionally-enshrined democratic principles and values and to perform effectively and efficiently. In both areas there are a number of challenges, largely determined by the macro-socio environment and the state of the public service. This article focuses firstly on the macro-social environment, and the ways in which it impacts on the public service. It is argued that there is a high demand on government to deliver a variety of services, largely a result of inherited inequalities and the current global economic situation. This high demand on service delivery is further affected by the state of the public service. Thus, the second part of the article is an examination of the state of the public service, utilising both secondary and primary sources, such as the results of social attitudes surveys, to demonstrate that the public service is characterised by poor governance, lack of accountability and transparency, incompetent and under-qualified officials, widespread corruption, and massive failures in planning, budgeting and implementation, and that most citizens are dissatisfied with the state of the public service.

In terms of the Constitution of the Republic of South Africa 1996, the public service is required to embody certain constitutionally-enshrined democratic principles and values and be able to perform effectively and efficiently. In this regard, the public service has to: firstly, be professional, efficient in the use of resources, development-oriented, impartial in the provision of services, responsive to the needs of the people, accountable, transparent and representative of the South African population; secondly, perform effectively and efficiently in meeting all the tasks of government; and, thirdly, have the institutional capacity and organizational ethos to perform the tasks of government effectively. In each of these areas there are a number of challenges for the public service, by and large determined by the macro-socio environment in which it operates and the state of the public service itself. These two elements are central in determining the capacity of the state to deliver services to the citizenry.

This article focuses on two broad areas: firstly, the macro-social environment; and secondly, the state of the public service. The analysis then concludes with a number of interventions introduced to deal with some of the challenges arising from the current state of the public service.

\section{Macro socio-economic environment}

It is necessary to begin with the macro-social environment within which the public service operates. The main characteristics of the social environment since 1994 are the explosion in the population of the country - including the influx of people from neighbouring countries and the consequent growth in demands on government to deliver a variety of services, and the political, social and economic inequalities inherited from the apartheid past. The latter have resulted in high poverty rates, low incomes for the majority of the population, a huge backlog in basic services and infrastructure, and high levels of unemployment, income disparities and a skills shortage. These in turn have given rise to a range of social ills, such as corruption, a high crime rate, protracted strikes, and widespread service delivery protests. Added to these are the scourges of HIV-Aids and the Tuberculosis pandemic. In addition to these challenges, 
government is faced with a situation in which there is an increase in the gap between what people expect and what government is realistically able to deliver, and where citizens expect the government to do more than before. ${ }^{\mathrm{i}}$

The statistics on the current social situation are quite revealing:

- Between 18 and 24 million South Africans (i.e. $45-55 \%$ of the population) are living in poverty, with between 8 and 10 million people living in extreme poverty.

- One in ten African children is malnourished; and one in four African children is stunted.

- While $10 \%$ of the population earn more than $50 \%$ of household income, the poorest $40 \%$ of the population account for less than $7 \%$ of the household income, with the poorest $20 \%$ accounting for less than $1,5 \%$.

- South Africa's Gini Coefficient places it as the most unequal country in the world.

- Official unemployment estimates indicate that close to $30 \%$ of the economically active population is without a job.

- Close to $12 \%$ of the population (5, 7 million people) are infected with HIV/AIDS (Akoojee, 2010: 263-4).

- South Africa's life expectancy rate has declined from 61, 1 years in 1990 to 47 in 2004.

- About 15 million South Africans receive some form of social grant.

- Although the education system has been reformed and all South Africans now have access to education, approximately 7,5 million people are functionally illiterate.

- Most people have access to health services, but public facilities are often under-resourced and unable to meet demands.

Despite the inequality in the society, there is equally, recognition that there have been a number of significant gains since 1994. The Deputy Chief Executive Officer of the South African Institute of Race Relations (SAIRR), for instance, stated in a report written in 2011 that:

The past 15 years have seen significant improvements in the living conditions of all South Africans, in all age groups, and across the economic spectrum. Today South Africa's living standards are higher than they have ever been. Service delivery has been one of the biggest successes of the ANC in government. On almost all measures, the number of households with access to formal houses, electricity, and clean water has increased sharply. This reality is quite contrary to what many South Africans believe (Cronje, 201, p.3).

The political environment has been shaped by the democratic state introduced in 1994. A variety of measures has been introduced to address some of the challenges South African society faces. South Africa is a country with an excellent constitution, relatively stable political system, numerous well-intentioned policies, including many that are pro-poor, and literally thousands of government-funded projects aimed at resolving social ills such as 
poverty and unemployment. South Africa's constitution is regarded as one of the most progressive in the world, and upholds the right of every citizen to access services in a democratic state. The constitutional process resulted in the development of legislation, policies and strategies that entrench this mandate in the overarching approach of government. This constitutional mandate requires the public service to shift towards a modern, democratic administration geared to cost-efficient service provision for its citizens.

Strong governance machinery of representative democracy has been inbuilt and these are amongst others, Parliament, Provincial Legislatures and Municipal and Traditional Councils. South Africa has well-established oversight institutions that support democracy and protect the rights of its citizens, such as the Office of the Public Protector, the South African Human Rights Commission, the Office of the Auditor General, the Commission for the Promotion and Protection of the Rights of Cultural, Religious and Linguistic Communities and the Gender Commission. South Africa also has strong civil society institutions, a free and courageous press, a vibrant political opposition, and independent courts (Cronje, 2011, p.3). On the international front, South Africa is highly regarded by all governments around the world as it plays a leadership role on the African continent and has cemented its leadership role in the Global South through its relationship with leading developing countries such as China, India and Brazil.

South Africa has the strongest economy on the continent. Since the late 1990s there has been a period of unbroken moderate economic growth. However, the South African economy failed to reach the target of $6 \%$ annual economic growth rate set after the 1994 elections to address service delivery backlogs. There are also other important structural constraints that have to be addressed. These include South Africa's low ranking in terms of economic competitiveness compared to other developing countries (Schwella, 2001, p.368). South Africa has experienced a decline in manufacturing since 1994, especially in sectors that are downstream, value-added and labour-intensive. Whatever growth has occurred, it has been in those sectors that are capital-intensive, or resource-based. However, the services sectors have expended tremendously since 1994, particularly those linked to debt creation, residential construction and consumption. But most of this growth has occurred without much job creation, with most employment only increasing in low-paying, unskilled functions within the wholesale and retail trade and the business services sectors. Economic growth in general has been largely driven by debt consumption. The economy remains over-reliant on the mining and minerals sector, while it is inadequately developed and diversified in the downstream manufacturing base (Mohamed, 2010, p.158-160).

The economic environment in 2011 has been characterised by rising oil prices, public sector wage negotiations (both of which have implications for inflation), and a strong currency. However, Cronje of the SAIRR points out that 'electricity shortages, low levels of entrepreneurship, and skills inadequacies remain structural impediments to growth' (Cronje, 2011: p.2). South Africa's high unemployment rate, and in particular the 50\% unemployment rate among young South Africans, is one of the major signifiers of economic dysfunction. Growth rates of between 6-8\% per annum are required to deal with this problem (Cronje, 2011, p.2). The Zuma administration introduced the New Growth Path to address 
unemployment, inequality and poverty in a strategy that is principally reliant on creating a significant increase in the number of new jobs in the economy, mainly in the private sector.

The global economic recession of 2009, the deepest in 70 years, resulted in a decline of 0,8 per cent in the world economy and 34 million people losing their jobs world-wide. In the same year, the South African economy declined by 1, 8 per cent, translating into 900,000 people that have lost their jobs. ${ }^{\text {ii }}$ These jobs lost were not recovered in 2010 because of modest economic growth. The current economic environment in 2011 is to some extent shaped by the potential for a double-dip recession. Weaknesses in the Euro zone have been a major factor dragging the global economic recovery and pose risks for economic stability. The most important challenge is the sovereign debt crisis of a number of European countries, which is having a negative effect on the global economic environment.

\section{State of the Public Service}

The Minister of Higher Education and Training, Blade Nzimande once stated that South Africa requires a strong public service that is both highly skilled and is 'people driven' iii William Gumede, in an article written for the Development Bank of South Africa (DBSA) identified these as two essential features of a developmental state. Firstly:

At the core of any developmental state is the state: efficient, well-coordinated and staffed with skilled employees. The state must have the administrative, technical and political capacity and competency to set national goals, make use of the market and implement these policies (Gumede, 2009, p.9).

And, secondly a developmental state which is also a democratic one has: ' ... to be inclusively embedded with their citizens. ... [T]he democratic developmental state is more inclusive and has greater citizen participation in decision-making, including economic decision-making' (Gumede, 2009, p.8-9). According to Gumede, the public service of a developmental state must consist 'of the nation's brightest and most talented [,] and appointments to it' must be 'based on merit, rather than politics'. It must also have an esprit de corps 'that puts attainment of the stated developmental goals and service above personal, political and' other narrow interests (Gumede, 2009, p.10). Greg Ruiters is spot on to say that 'The public sector in South Africa includes every sphere of government, the various organs of the state, its boards and public enterprises' (Ruiters, 2006, p.1). The public service employs about 1, 2 million people. Of these, 63 per cent are employed in the social services sector (health, social development, education, and home affairs), followed by 20 per cent in the criminal justice sector.

The media often critically draws attention to government failures in areas such as education, the breakdowns in the criminal justice system, including policing, non-delivery in the health and hospital sectors, deteriorating infrastructure, municipal services and so on. Attention is often drawn to specific government departments and municipalities that are plagued by mismanagement, corruption and a failure of financial systems.

At a general level, one has to recognize some of the following negative features of the South African public service: poor governance, lack of accountability, lack of transparency, incompetent and under-qualified officials, widespread corruption, and massive failures in 
planning, budgeting and implementation. These have given rise to service delivery failures, massive under-spending by government departments, negative audits opinions and significant cases of unauthorised, fruitless, wasteful and irregular expenditure by government structures at all spheres of government, inadequate planning, budgeting and implementation and numerous cases of fraud and corruption involving senior public officials.

According to Derek Luyt of the Public Service Accountability Monitor (PSAM), a major obstacle to achieving the goals of government policies, for instance those aimed at poverty alleviation, is poor governance, which includes not simply corruption, but also poor performance of government officials in their management of public resources and a lack of political will to act against underperforming officials. The poor management of public resources translates directly into poor public service delivery implementation, and thus obviously undermines many government policies. What Luyt is arguing is that public resources are not efficiently utilized due to inadequately skilled public officials who are not made to account for their underperformance. The lack of accountability is seen to be a potential cause of this poor governance (Luyt, 2008, p.3).

Under-spending by government departments in a situation of substantial service delivery and infrastructure backlogs is routinely criticized from many quarters year after year. Examples of under-spending include the R1,4-billion under-spending of the KwaZulu-Natal department of Health for the 2010/2011 financial year. ${ }^{\text {iv }}$ The Gauteng Department of Finance, on the other hand, recorded R1,5-billion under-spending on infrastructure projects for the same period. National departments have been equally responsible in this area. In the year 2007/08, the Department of Housing recorded an under expenditure of 4.4\% equivalent to R395.6 million, which decreased in 2008/09 to $0.1 \%$, while the Department of Health has consistently under spent more than R300 million in both periods at an average of $2.45 \%$ (Skenjana, nd)). The PSC acknowledged the problem of under-spending in 2008 when it stated that "the country cannot afford to have funds being returned unspent ... [while there are still such] ... backlogs in the delivery of basic services" (Public Service Commission, 2008, p.31).

More than half of the 283 municipalities, and about $20 \%$ of national and provincial governments receive adverse or qualified audit (Centre for Development and Enterprise, 2009: 3). The main reasons for municipalities not getting clean audits are serious financial misstatements, non-compliance with laws and regulations, and lapses in governance arrangements (internal audit, audit committees and risk management). The national Department of Housing in 2007/08 financial year received a qualified report while the Department of Education and the Department of Health had an adverse audit opinion (Skenjana, nd). It is a complex mixture of factors that account for departments receiving qualified reports or adverse opinions, including the lack of officials with the relevant technical skills.

Among the key weaknesses identified are poor planning and budgeting. This does not overrule poor implementation. There are numerous instances in which inadequate planning and budgeting have led to disastrous consequences. These inadequacies partially account for under-spending by government departments. It is critical for government that public officials are adequately skilled to develop coherent plans with appropriate budgets. However, even 
when this is the case there may be cases of poor implementation of plans. Not long, a decade ago:

... the discrepancies between policy and implementation are largely caused by unrealistic policies, and a lack of managerial expertise. Another key finding is that policy implementation has suffered from the absence of a people driven process. Insufficient coordination of policy implementation is cited in virtually all sectors, and has significantly hampered the implementation of policies. In addition, insufficient staffing and capacity of all three spheres of government, as well as the linkages between them, have largely worked against the successful implementation of policies (Khoza, 2003, p.49).

Public sector corruption remains one of the main threats to the achievement of the goals of a developmental state in South Africa. It affects all levels of the public service. According to the PSC, 7,766 cases of corruption were reported to the national anti-corruption hotline in 2010. However, in 63 per cent of these cases, no feedback was received from the departments to which the cases had been referred for investigation. Almost two thirds of departments do not have a basic capacity to investigate charges of corruption. Officials who are found guilty generally receive very lenient punishments, such as written warnings, and these matters are not reported to the police (Landman, 2011). The PSC found that the common forms in which corruption manifests itself are fraud and bribery (1,511), mismanagement of Government funds (870), procurement irregularities (720) and appointment irregularities (627). Financial misconduct cases are prevalent in the public service at national, provincial and local spheres of government. In the KwaZulu-Natal Provincial Health Department, for instance, 76 disciplinary cases involving fraudulent activity resulted in 17 dismissals, 13 resignations, and 14 written warnings. ${ }^{\mathrm{v}}$

Corruption is often viewed as a societal malady. The public sector is invariably the key culprit of harbouring this deadly phenomenon without ruling out the other sectors to say the least. Public officials are expected to demonstrate traits of public honesty, integrity and accountability, yet, they behave otherwise. Unfortunately, because many public officials have not received proper training for the positions they hold, the exposure and risk to corrupt influences is very high. The challenge starts with a flawed recruitment process where political patronage and sheer nepotism take precedence over merit. It is therefore not surprising that there is a serious problem of corruption in the public sector.

Corruption, when coupled with inefficiency in procurement and poor planning, results in considerable wastage of state funds and undermines the capacity of the state to deliver services. Procurement is a crucial and sensitive area in government with progressive legislation guiding all processes. However, the consistency of unauthorised expenditure shows the weaknesses of the control environment. There are cases where officials are going beyond their delegated authority in approving payments or appointment of service providers (Skenjana, nd). Improved management capability, governance, enforcement, and oversight in government, as well as greater transparency and accountability in procurement systems are required to resolve these problems. ${ }^{\mathrm{vi}}$ These are all areas within the mandate of the PSC.

The effectiveness of managers in the Public Service group impacts on the overall ability of 
the Public Service to deliver on its mandate. However, one problem is that managers constitute only a small proportion of the Public Service (0, 4 per cent in 2002) with the majority of 60 per cent serving in national departments as opposed to 40 per cent in provincial departments in 2002). Added to these problems is the high level of turnover of middle and senior management which is due largely to negative perceptions of working conditions in the public service, a high demand for qualified professional staff in the private sector and growing international opportunities for skilled South Africans (Department of Public Service and Administration, 2007, p.12, 37, 66).

From 1994, the ANC-led government also embarked on a process of reforms and transformation of the public service. This was necessary both in terms of making the public service more representative of the population, in a situation where $84 \%$ of managers in the public service were white in 1994 (Ruiters, 2006, p.127) and to transform the institutional culture from advantaged few to providing services to all. However, the reforms and transformation resulted in a skills exodus that affected government's ability to spend revenue and deliver services. This problem has been compounded by high vacancy rates at senior management levels (Ruiters, 2006, p.129). For instance, Naidoo has shown that the average annual mobility rate across the public service is $32 \%$ in national departments and $28 \%$ in provincial departments, while the vacancy rate in national departments is $25 \%$ for senior management and $31 \%$ for middle management (Naidoo, 2008, p.124). Another problem is that the contracts of senior managers are often of short duration; three years in the case of Directors-General. This does not allow for continuity at the senior levels of the public service as compared to other countries.

The skills levels of many senior public servants have also come under criticism. For instance, Greg Ruiters points out that research conducted in 2005 showed that most municipal managers were under-qualified for their jobs (Ruiters, 2006, p.130). Sangweni and Mxakato-Diseko state that the South African public service was 'groping in the dark in an infant state of ability to fulfil its functions, implying mediocrity, weakness, ineptitude and a lack of cognizance of the urgency to "raise the bar" on service delivery' (Sangweni and Mxakato-Diseko, 2008: p.41). Butler adds to this 'a prevalence of muddled understandings of the challenges facing the nation; cultural and political clashes between officials; the lack of any common ethos; the absence of uniform training; limited loyalty in the service; little commitment to excellence; failures of proactive or anticipatory governance; high mobility of public servants in pursuit of senior positions, resulting in limited institutional memory; and excessively rapid turnover of DGs and heads of departments (HoDs)' (Butler, 2010, p.193). Attracting and retaining the best talent in the public service always remains a challenge.

Among the crucial requirements of the public service in a democratic developmental state is that it must be both accountable and transparent. In its submission in early 2009 to the Ad Hoc Committee of the National Assembly enquiring into progress with service delivery, the Institute for Accountability in Southern Africa, an organization known to be critical of the ANC government, highlighted that:

When those in positions of authority, be it political or administrative authority, are required (by those who elect or appoint them) to reasonably explain their conduct and to justify their 
decisions properly, then the conditions for exacting accountability may be said to be in place. The public administration, which is tasked with providing service delivery [C 195 (1)] accountably and transparently, is answerable to the public for what it does and does not do in fulfilling its functions. Professionalism and impartiality are basic requirements for proper, constitutionally compliant public administration [C 195 (1)]. Both are notably absent in the public administration of South Africa. This has led to deterioration of service delivery in a number of key areas and consequently to protest action by the public ranging in its illegality from rates and rent boycotts to violently destructive criminality involving malicious damage to property, assaults, disruption and even loss of life (Institute for Accountability in Southern Africa).

One of the serious challenges facing the Public Service in South Africa is how to deal with the ANC's policy of cadre deployment, and the consequences of this policy. One inference that seems to be common is that: 'The ANC's deployment strategy systematically places loyalty ahead of merit and even of competence, and is therefore a serious obstacle to an efficient public service' (Centre for Development and Enterprise, 2009: 8). Politically connected, and in many cases, incompetent people are deployed to positions leading to demoralization in the public service. In addition, unqualified people are unable to deliver services efficiently and effectively, while politically connected public officials may feel that their competence has little or no bearing on their employment (Centre for Development and Enterprise, 2009: p.24). High office in the public service is increasingly seen as a route to upward mobility (Ruiters, 2006, p.134). Whether cadre deployment is abused and wrongly judged or not, the motive behind it is questionably worrisome. One argues that competency and ethical correctness of the incumbents should always supersede political correctness hence it is critical that any person must pass an ethical test as a basis prior serving the state.

There are a number of areas in which the public service has been criticized for its lack of accountability, transparency and fairness. One particularly volatile area is the delivery of housing. Criticism has ranged from the choice made by a local government structure to provide housing in one area and not another and the allocation of houses to one racial group to the disadvantage of another, to corruption and unfair practices in the allocation of housing to individuals. The recent protest in Alexandra Township near Johannesburg is an example of the latter. Township residents who had evidence that they had been on housing waiting lists for years gathered to protest against the apparent allocation of RDP houses to recently-arrived foreigners. Among the claims of corruption made by township residents was that people were required to pay a bogus fee of R3 000 to R6 000 to obtain an RDP house (Sowetanlive, 2011).

\section{State of the Local Government}

Although, legally, the local sphere of government is not recognized as part of the public service, it cannot be debunked and delinked from the national and provincial spheres of government which are in the domain of the public service. It is widely recognized as a matter of fact that, in terms of policy implementation, the weakest links in the public service are at the provincial and local spheres of government (Luyt, 2008: p.4). Although some provincial governments and municipalities perform well, the performance of the overwhelming majority of provinces and municipalities is appalling, especially the latter. 


\section{Macrothink}

Journal of Public Administration and Governance

ISSN 2161-7104

2013, Vol. 3, No. 1

The importance of the local sphere of government has been put in perspective. 'Local government is now positioned as the key site of delivery and development and stands central to the entire transformation project of post-apartheid South Africa'. Local government is generally facing a number of serious capacity challenges. It is estimated that " $60 \%$ of municipalities perform $50 \%$ or less of their constitutionally mandated functions". Although these concerns are specific to local government, one cannot underscore effective and efficient national and provincial departments outside the context of the performance of local government (Layman, 2003: p.12).

In the State of Local Government report of 2009, the Department of Cooperative Governance and Traditional Affairs (COGTA) found that:

From evidence to date, it is clear that much of local government is indeed in distress, and that this state of affairs has become deeply-rooted within our system of governance. Therefore underpinning the analysis are some key questions, such as how deep-rooted is the state of distress in our local municipalities, what are the causes, and through what measures do we address these fault-lines in our governance arrangements? (Department of Cooperative Governance and Traditional Affairs, 2009a, p.4-5.)

Overall, local municipalities suffer from deficiencies in planning, project management, financial management and technical skills (Butler, 2010, p.191). COGTA (2009) identified the following service delivery and governance problems in municipalities that have persisted over the years:

- Huge service delivery and backlog challenges, e.g. housing, water and sanitation;

- Poor communication and accountability relationships with communities;

- Problems with the political-administrative interface;

- Corruption and fraud;

- Poor financial management, e.g. negative audit opinions;

- Number of (violent) service delivery protests;

- Weak civil society formations;

- Intra- and inter-political party issues negatively affecting governance and delivery; and

- Insufficient municipal capacity due to lack of scarce skills.

The Department identified a host of 'root causes of the current state of distress in many of the county's municipalities' that covered areas such as governance; planning, local economic development and service delivery; finance; and labour relations. Among the root causes of the state of distress were:

- Inappropriate national and provincial government policies, practices and onerous requirements;

- Socio-economic conditions prevailing in many municipalities that are not been adequately addressed through macro, micro-economic and industrial policies and plans of the 
State;

- Political parties that are undermining the integrity and functioning of municipal councils through intra and inter-party conflicts and inappropriate interference in councils and administration;

- A breakdown of values at a societal level that is breeding unethical behaviour, corruption, culture of non-payment, and lack of accountability

- Communities which are engaging in destructive forms of protest including withholding of payment for local taxes and services;

- Those municipalities that are not geared for delivering basic services and are not responsive and accountable enough to residents; including to failure to involve communities in their own development;

- Absence of communications resources (people, technology, equipment processes) and no accountability for how and when municipalities communicate to communities (COGTA, 2009b, p.18-19).

A Turnaround Strategy for Local Government was subsequently devised in December 2009 outlining a range of interventions. However, in the run up to the local government elections of mid 2011 the Institute for a Democratic Alternative in South Africa (IDASA) conducted a survey which found 'that citizens have so far not seen any significant impact from the Turn Around Strategy that was initiated by COGTA at the end of 2009 on the performance of their local government' (Institute for a Democratic Alternative in South Africa, 2001, p.3). IDASA concluded that 'only one in ten citizens is at present satisfied with the quality of service delivery provided by the district and municipal councils, down from four in ten citizens four years ago just before the local government elections in 2006'. It infers that this arises from: firstly, an increase in the gap between what people expect and what government is realistically able to deliver due to population growth and international and national migration, and because citizens expect the government to do more than before; secondly, the lack of responsiveness of the councils to address the important issues identified by its citizens due to the fact that the councils have only limited power and discretionary resources to address their own priorities as identified by their citizens, and consultation and participation structures do not function optimally; and thirdly, citizens increasingly drawing their perception on the quality of governance - i.e. poor communication, lack of transparency, and increased corruption and nepotism - into the equation of their assessment of the performance of local government (Institute for a Democratic Alternative in South Africa, 2011, p.36).

Local government remains in a state of distress despite new interventions since December 2009. According to Institute for a Democratic Alternative in South Africa (IDASA):

Our findings confirm that the local government crisis in South Africa is deepening and starting to become a structural systemic problem that seems to become more and more embedded in our actual system of local government as the governance issues raised by this survey (lack of transparency, lack of communication between council and citizens and lack of social accountability) relate to a disdain of basic democratic governance principles and values 
that are increasingly sacrificed by politicians for individual benefits and political power ((Institute for a Democratic Alternative in South Africa, 2011, p.37).

Whilst it is true that the 2009 turnaround strategy has not yielded fruitful results and meaningful impact, the IDASA analysis is premature to judge. However, despite being premature, the strategy itself is problematic in that it is short-lived, and cannot be used as a reliable instrument to assess impact.

In an analysis of public confidence in government institutions using Social Attitudes Surveys of the Human Sciences Research Council (Roberts, 2008: 10-11) over a ten year period between 1998 and 2008 in The State of the Cities Report 2011, it is indicated that confidence in national and local government institutions improved between 1998 and 2004 and declined steadily thereafter. In 2008, 51\% of the public felt confident in the national government, while only $38 \%$ felt confident in local government. The study concludes that there appears to be growing unease and scepticism about municipal performance (South African Cities Network, 2012, p.122-3). It adds that:

Municipal mismanagement and corruption are obvious sources of community mistrust. Under the authority of the president, the Special Investigation Unit subjected the two metros with the biggest declines in local trust, Ekurhuleni and Tshwane, to wide-ranging investigations into alleged corruption. Announced in November 2010, the official terms of reference for investigation include procurement processes, mismanagement, wasteful spending, irregular staff appointments, and misappropriation of the municipality's money and assets over a four-year period from 2007-2010. There were also allegations of tender rigging in Ekurhuleni's waste management department, involving contracts worth about R850 million (South African Cities Network, 2012, p.124).

The HSRC survey for 2008 revealed that people living in the metropolitan areas (i.e. eThekwini, Cape Town, Johannesburg, Tshwane, Ekurhuleni, Msunduzi and Nelson Mandela Bay) were mostly in agreement that their municipalities were making good progress with giving all South Africans equal access to services, with nearly half of respondents agreeing and a third disagreeing with this statement. More respondents also agreed that people were treated with respect. However, equal proportions of respondents felt that municipalities were not providing quality and value for money in municipal services delivered. The majority of respondents felt that their municipalities were not consulting communities, providing them with information and responding to their concerns. The overall message seems to be that the metros are improving service delivery, but are not communicating or responding quickly enough to people's problems (South African Cities Network, 2012, p.127). The IDASA survey indicates that the latter remain a serious concern.

Also, the HSRC survey reveals that people living outside the metros are generally less positive about municipal services. Only about a third of respondents outside the metros gave municipal performance a positive rating. At least half of all respondents felt that their municipalities were not consulting enough, were not responding quickly to their concerns, providing regular information, fixing their problems, providing good quality services, giving good value for money, treated people with respect or increased equal access (South African 
Cities Network, 2012, p.127).

One problem identified by civil society organizations is the technicist, procedural and instrumentalist approach of public participation in South Africa. It is recommended instead, that 'more dynamic, more meaningful and more varied modes of participation be nurtured' (Van Donk, 2011, p.5). It is argued that: 'While the government has taken various steps to remedy the serious problems facing local government and poor service delivery, its narrow commitment to institutionalised forms of participation and its rejection of informal (but potentially more inclusive) spaces of democratic expression of voice has resulted in missed opportunities to gain insights into the complex and varied reasons behind community protests' (Van Donk, 2011, p.9).

\section{Interventions}

A whole range of new structures and procedures have been put in place to encourage more effective and efficient service to the public. For instance, one can make reference to inter-governmental forums such as the President's Coordinating Council formed in 1999, which was made up of the President, the then Minister of Provincial and Local Government, and provincial premiers. From 1996 inter-governmental forums have been established along sectoral lines, such as finance, consisting of national ministers and their provincial counterparts such as MinMECs. These inter-governmental forums were extended to the public service in the form of the Forum of South African Directors-General, which brought together national and provincial directors-general. Such forums encouraged information sharing and consultation, as well as the alignment of policies and coordination of actions across the different spheres of government (Layman, 2003).

A range of measures have been introduced over the years to deal with some of the maladies affecting the public service. These include a number of processes, instruments and institutions that collectively promote and support integrity and anti-corruption in public administration. Some examples are the Code of Conduct, whistle blowing legislation and legislative frameworks that promote transparency and accountability, among others (Public Service Commission, 2010, 6). The Code of Conduct for the public service clearly states that an employee should not use his or her official position to obtain private gifts or benefits for self-enrichment during the performance of his or her official duties nor should he or she accept any gifts or benefits when offered as these may be construed as bribes. However, this important requirement aimed at promoting transparency and accountability is often ignored. To curb this, The National Anti-Corruption Hotline (NACH) was established in September 2004. In addition, a number of external interventions have been introduced, such as the launch of anti-corruption watch by the Congress of South African Trade Unions (COSATU) and members of civil society in January 2012.

Also, the government has put in place clear planning frameworks such as the Medium Term Strategic Framework developed by the Presidency, departmental medium term strategic plans, departmental annual performance plans, the annual Programme of Action of government which facilitates the alignment of departmental activities around crosscutting priorities, the National Spatial Development Perspective which fosters spatial alignment, the Provincial 


\section{Macrothink}

Journal of Public Administration and Governance ISSN 2161-7104

Growth and Development Strategies and Integrated Development Plans at the local sphere of government (Public Service Commission, 2010, p.18).

A Ministry of Performance Monitoring and Evaluation in the Presidency was introduced by the Zuma administration to ensure that the public service is accountable, transparent and effective through the application of a new performance management system. This includes the National Planning Commission in the office of the President to develop a national growth path and industrial policy action. Measures for individual accountability have also been introduced, such as that for budgets in relevant provisions of the Public Finance Management Act, 1999 (act 29 of 1999). Measures ensuring accountability for performance of individual public servants have also been introduced, such as the requirement that senior managers sign performance agreements as provided for in the Senior Management Service Handbook. A Senior Management Service (SMS) has been established, which allows departments to recruit and retain senior officials more effectively (Butler, 2010, p.193). More recently, emphasis has been placed on an outcomes-based approach in the public service to accelerate service delivery.

\section{Conclusion}

Given the enormous demands placed on government, attention still needs to be given in a number of areas to improve both the ways in which the public service embodies constitutionally-defined principles and values and performs effectively and efficiently. It is necessary to strictly implement the code of conduct for civil servants and to encourage an institutional culture that supports ethical behaviour to ensure that the South African public service embodies those principles and values that are enshrined in the Constitution. This can also be encouraged by promoting a professional civil service that is subject to merit-based selection and promotion processes, and investing in the recruitment, training and retention of public servants. A human resource management system needs to be implemented that improves the capacity of public officials to deliver the services so badly needed by the millions of citizens. Steps that have been introduced to deal with corruption need to be fully supported. Above all else, government, recognising that the greatest challenge is getting government departments to pay serious attention to the variety of recommendations made by numerous institutions, organisations and individuals to enhance service delivery, must improve mechanisms for public participation and government's communication with the public.

\section{References:}

Akoojee, S. (2010). 'Intermediate skills development in South Africa: Understanding the context, responding to the challenge, in O. Edigheji (ed.), Constructing a democratic developmental state in South Africa: Potentials and challenges, (Human Sciences Research Council Press: Cape Town).

Butler, A (2010). 'Consolidation first: Institutional reform priorities in the creation of a developmental state in South Africa', in Edigheji (ed.), Constructing a democratic developmental state in South Africa: Potentials and challenges, (Human Sciences Research 
Council Press: Cape Town). 2013, Vol. 3, No. 1

Centre for Development and Enterprise (2009). 'South Africa's public service: Learning from success', CDE Round Table Occasional Paper No. 13.

Cronje, F (2011). 'South Africa 2011: A bullet point overview of key social and economic trends', Occasional Paper, South African Institute of Race Relations, Johannesburg,

COGTA (2009a). 'State of Local Government in South Africa: Overview Report - National state of local government assessments', Department of Cooperative Governance and Traditional Affairs, Working Documents, Available at www.pmg.org.za (Accessed on 18 October 2011).

COGTA (2009b). Local Government Turnaround Strategy, Department of Cooperative Governance and Traditional Affairs, Pretoria.

Department of Public Service and Administration (2007). The Human Resource Development Strategy for the Public Service 2002 - 2006, First Edition, Government Printer, Pretoria.

Gumede, W (2009). 'Delivering the democratic developmental state in South Africa', Development Planning Division Working Paper Series No. 9, Development Bank of South, Midrand,1-24.

Institute for Accountability in Southern Africa, Submission to the Ad Hoc Committee of the National Assembly enquiring into progress with service delivery, available at www.iafaisa.org. (Accessed on 18 October 2011).

Khoza, MM (2003). 'Towards Effective Delivery: Synthesis Report on the project entitled 'Closing the gap between policy and implementation in South Africa', Research Report No. 98, Centre for Policy Studies, Johannesburg, Cited in P.A. Brynard, 'Policy implementation: Lessons for service delivery', Paper presented at the $27^{\text {th }}$ African Association for Public Administration and Management Annual Roundtable Conference, Livingstone, Zambia, 5-9 December 2005.

Landman, W (2011). 'South African public service is in a state of crisis', Leader, 13 May.

Layman, T (2003). Inter-governmental relations and service delivery in South Africa: A ten year review. Report commissioned by the Presidency of South Africa, Pretoria.

Luyt, D (2008). 'Governance, Accountability and Poverty Alleviation in South Africa', Paper presented at the United Nations Social Forum, Geneva, Switzerland.

Mohamed, S (2010). 'The effect of a mainstream approach to economic and corporate governance on development in South Africa', in O. Edigheji (ed.), constructing a democratic developmental state in South Africa: Potentials and challenges, (Human Sciences Research Council Press: Cape Town).

Naidoo, V (2008). 'Assessing racial redress in the public service', in K. Bentley and A. Habib (eds.), Racial Redess and Citizenship in South Africa, (HSRC Press: Cape Town).

Public Service Commission, (2008) State of the Public Service Report, Public Service Commission, Pretoria. Available at www.info.gov.za. (Accessed on 20 October 2011). 


\section{MlMacrothink}

Journal of Public Administration and Governance ISSN 2161-7104 2013, Vol. 3, No. 1

Public Service Commission, (2010). State of the Public Service Report: Integration, Coordination and Effective Public Service Delivery, Public Service Commission, Pretoria. Available at www.info.gov.za. (Accessed on 20 October 2011).

Roberts, B. (2008). 'Between Trust and skepticism: Public confidence in institutions', HSRC Review, 6(1) 10-11

Ruiters, G (2005). 'Public services: Transformation or stasis', in Public Services Yearbook 2005/6. Pretoria. Available at ww.queensu.ca. (Accessed on 20 October 2011).

Schwella, E (2001). 'Public sector policy in the new South Africa: A critical review', Public Performance and Management Review, 24(4), 367-388.

Sangweni, SS and Mxakato-Diseko, N (2008). 'It does not matter what slant or take you have on the developmental state: At the end of the day, a strong, coherent and astute public service is critical', in B. Turok (ed.), Wealth does not trickle down, New Agenda, Cape Town. Cited in

Butler, A. (2010). 'Consolidation first: Institutional reform priorities in the creation of a developmental state in South Africa', in Edigheji (ed.), constructing a democratic developmental state in South Africa: Potentials and challenges (Human Sciences Research Council Press: Cape Town).

Skenjana, N (nd) 'Exploring the pattern of expenditure in government departments', www.afesis.org.za. (Accessed on 20 October 2011).

South African Cities Network, State of the Cities Report 2011, Johannesburg. Available at www.sacities.net. (Accessed on 20 October 2011).

Van Donk, M (2011). 'Foreword', in Good Governance Learning Network, Recognising Community Voice and Dissatisfaction: A civil society perspective on local governance in South Africa, (Good Governance Learning Network: Cape Town

\section{Endnotes:}

${ }^{\mathrm{i}}$ This is a conclusion drawn from a survey conducted by the Institute for a Democratic Alternative in South Africa (IDASA) just prior to the local government elections in mid-2011. Refer to Institute for Accountability in Southern Africa, 2011.

ii Minister Pravin Gordhan's Budget Speech for 2010, House of Parliament, Cape Town.

iii Address at the Leadership, governance and public policy in the public sector", University of Pretoria, Pretoria, 15 February 2011.

iv 'Progress Report on key Health service delivery initiatives in Health', presented by MEC of health, Dr Sibongiseni Dhlomo, KwaZulu-Natal Provincial Legislature, 1 September 2011. $v$ 'Progress Report on key Health service delivery initiatives in Health', presented by MEC of health, Dr Sibongiseni Dhlomo, KwaZulu-Natal Provincial Legislature, 1 September 2011.

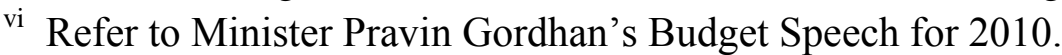

